\title{
Wickerhamiella pagnoccae sp. nov. and Candida tocantinsensis sp. nov., two ascomycetous yeasts from flower bracts of Heliconia psittacorum (Heliconiaceae)
}

\author{
Correspondence \\ Carlos A. Rosa \\ carlrosa@icb.ufmg.br
}

\author{
Anne C. Barbosa, ${ }^{1}$ Camila G. Morais, ${ }^{1}$ Paula B. Morais, ${ }^{2}$ Luiz H. Rosa, ${ }^{1}$ \\ Raphael S. Pimenta, ${ }^{2}$ Marc-André Lachance ${ }^{3}$ and Carlos A. Rosa ${ }^{1}$ \\ 1 Departamento de Microbiologia, ICB, CP 486, Universidade Federal de Minas Gerais, \\ Belo Horizonte, MG 31270-901, Brazil \\ ${ }^{2}$ Laboratório de Microbiologia Ambiental e Biotecnologia, Campus Universitário de Palmas, \\ Universidade Federal do Tocantins, Palmas, TO 77020220, Brazil \\ ${ }^{3}$ Department of Biology, University of Western Ontario, London, ON N6A 5B7, Canada
}

Flower bracts of plants of the genus Heliconia (Heliconiaceae) form a complex micro-environment containing several species of insects and micro-organisms (Ruivo et al., 2006). Heliconia, the single genus within the family Heliconiaceae, has a primarily neotropical distribution with approximately 215 species native to Central and South America and six species native to the South Pacific. Heliconia species are herbaceous monocots characterized by banana-like leaves, a pseudostem and inflorescences consisting of thick, coriaceous bracts that subtend partial florescences of cincinni (Schumann, 1900; Weberling, 1982). The actual flower emerges in an inflorescence from the large showy bracts, almost always at the end of long, leafy shoots. Flowers of New World taxa are morphologically specialized for hummingbird pollination (Stiles, 1975; Gill, 1987; Taylor \& White, 2007).

In their natural habitat, Heliconia species typically occupy clearings on the forest floor in humid tropical rainforests, especially in places where sunlight can penetrate through the leaf canopy, and also along river banks. The bracts are often filled with water and house a distinctive aquatic micro-ecosystem colonized by insects and a diverse

The GenBank/EMBL/DDBJ accession numbers for internal transcribed spacer, 5.8S rRNA gene and D1/D2 variable domains of the large subunit of the rRNA gene for strains UFMG-F18C $1^{\top}$ and UFMG$\mathrm{F} 16 \mathrm{D} 1^{\top}$ are HO593535 and HO593534, respectively. microbiota. The nectar in the bracts is the source of food for these organisms (Schnittler \& Stephenson, 2002). The flower bracts are also visited by hummingbirds (Stiles, 1975). Insects and hummingbirds may act as vectors of the micro-organisms among different plants. Yeasts are components of the microbial communities associated with these flowers. Four Candida species, Candida flosculorum, Candida heliconiae, Candida picinguabencis and Candida saopaulonensis, have been isolated from flower bracts of Heliconia species in Brazil (Ruivo et al., 2006; Rosa et al., 2007).

During a study on yeasts associated with flowers, 13 isolates of an ascosporogenous yeast were obtained from 10 flower bracts of Heliconia psittacorum collected in the riparian forest of Formiga Falls, a Cerrado ecosystem in the State of Tocantins, Brazil. These strains are shown to represent a novel species; its closest relative was Candida jalapaonensis of the Wickerhamiella clade. Another two isolates of a novel asexual ascomycetous yeast species were also obtained from two flowers of $H$. psittacorum. This novel species belongs to the Metschnikowiaceae clade. The names proposed for the novel species are Wickerhamiella pagnoccae sp. nov. and Candida tocantinsensis sp. nov.

Samples of flower bracts of Heliconia psittacorum were collected in the riparian forest of Formiga Falls, a Cerrado ecosystem in the Jalapão Region, Brazil. The Cerrado 
ecosystem is one of the richest tropical savannas and is considered to be a biodiversity 'hotspot'. The Jalapão region is a protected area of almost $53340.90 \mathrm{~km}^{2}$ located in the eastern part of Tocantins. Although the Jalapão is within the Cerrado biome, this area is strongly influenced by neighbouring ecosystems such as the Amazon forest to the north, the Cerrado (Brazilian savanna) to the south and west and also the caatinga (semi-desert) to the east (Colli et al., 2009). The Formiga Falls area is close to the Formiga River within the sandy terrain of Jalapão State Ecological Park.

Fifteen flower bracts of $H$. psittacorum were collected in April 2009. The extrafloral nectaries were gently scraped with a sterile inoculation loop and streaked on plates of YM agar $(0.3 \%$ yeast extract, $0.3 \%$ malt extract, $0.5 \%$ peptone, $1.0 \%$ glucose, $2 \%$ agar and $0.02 \%$ chloramphenicol). In Heliconia, within each bract there is a coil of inconspicuous flowers. The flowers are arranged in two whorls of three and form a lower lip subtended by ridged bracteoles; the septal nectaries are present in the syncarpous inferior ovary. Hence, although the actual sampled substrate was the nectary of each inflorescence, there may have been cross-contamination with microorganisms present in the tiny flowers. Plates were incubated at room temperature $\left(25 \pm 3{ }^{\circ} \mathrm{C}\right)$ for $3-8$ days. Each different yeast morphotype was purified and maintained on YM slants or in liquid nitrogen for later identification. The yeasts were characterized using standard methods (Yarrow, 1998). Preliminary identities were determined using the keys of Kurtzman \& Fell (1998). Sporulation was investigated using malt extract, glucoseyeast extract, yeast carbon base plus $0.01 \%$ ammonium sulfate (YCBAS), dilute (1:9) V8, Fowell's acetate and YM agars at $22{ }^{\circ} \mathrm{C}$ for up to 4 weeks.

The ITS, 5.8S rRNA gene and D1/D2 variable domains of the large subunit of the rRNA gene were amplified by PCR directly from whole cells, as described previously (Lachance et al., 1999). The amplified DNA was concentrated and cleaned on QIAquick PCR columns (Qiagen) and sequenced using an ABI sequencer at the John P. Robarts Research Institute (London, Ontario, Canada). Sequences were assembled, edited and aligned with the program MEGA4 (Tamura et al., 2007). Phylogenetic placements of the novel species were based on maximum-parsimony analysis of D1/D2 largesubunit rRNA gene sequences. The tree is a bootstrap consensus tree obtained using the Close-Neighbour-Interchange algorithm (Nei \& Kumar, 2000) with search level 2 with initial trees obtained by random addition.

\section{Species delineation and ecology}

Several different yeast species were isolated from the $H$. psittacorum bracts. These species included Aureobasidium pullulans, Candida flosculorum, Candida intermedia, Candida species, Cryptococcus species, Pichia fermentans, Pseudozyma antarctica, Pseudozyma hubeiensis and Wickerhamiella species. The species identified as a member of the genus Wickerhamiella was isolated from 10 flowers and produced conjugated asci with one ascospore per ascus. Analysis of D1/ D2 large-subunit rRNA gene sequences (Fig. 1) confirmed that this yeast belonged to the Wickerhamiella clade and that it was phylogenetically related to Candida jalapaonensis. This species differed from Candida jalapaonensis by seven nucleotide substitutions spread among six locations along

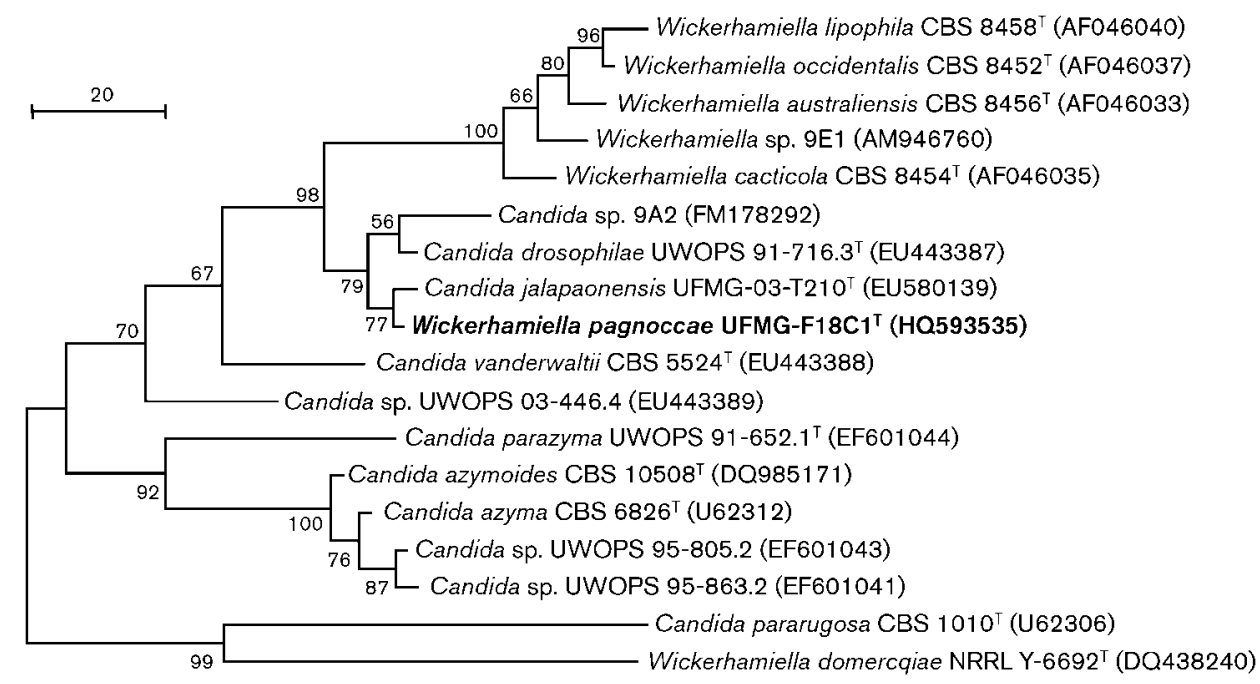

Fig. 1. Phylogenetic placement of Wickerhamiella pagnoccae sp. nov. based on maximum-parsimony analysis of sequences of the D1/D2 domains of the large-subunit rRNA gene. The bootstrap consensus tree was inferred from 1000 replicates; bootstrap values are shown at nodes. The tree was obtained using the Close-Neighbour-Interchange algorithm (Nei \& Kumar, 2000). Positions with less than $95 \%$ site coverage were eliminated. The final alignment contained 486 positions. The program MEGA4 (Tamura et al., 2007) was used. Bar, number of nucleotide changes. 
the sequence. The mating types of the novel species were crossed with the type strain of Candida jalapaonensis, but asci or signals of conjugation were not seen. The name Wickerhamiella pagnoccae sp. nov. is proposed to accommodate these isolates.

W. pagnoccae, a heterothallic, haplontic species, formed conjugation tubes and one spheroid ascospore per ascus after $20 \mathrm{~h}$ of incubation on dilute (1:9) V8 agar at $24{ }^{\circ} \mathrm{C}$. The type strain, UFMG-F18C1 ${ }^{\mathrm{T}}$, was assigned arbitrarily to mating type $h^{+}$of the species; six other isolates (UFMGF1B1, F7A2, F8F1, F13A2, F20C3 and F22A1) have the same mating type. The designated allotype is strain UFMG-F8F2; five other strains (UFMG-F1C1, F7A3, A13A1, F20C3 and F22A2) have the same mating type $\left(h^{-}\right)$. As the mating types of the novel species appear to be distributed more or less equally, we conclude that the species is sexually active. $W$. pagnoccae differed from its nearest relative by its inability to assimilate galactose, glycerol, acetone and hexadecane, which are positive for Candida jalapaonensis, and its ability to grow on $10 \% \mathrm{NaCl}$ plus $5 \%$ glucose medium. This novel species is the second nitrate-negative species in the genus (Wickerhamiella lipophila is the other nitrate-negative species); nitrate is assimilated by most species of the genus Wickerhamiella (Lachance \& Kurtzman, 2011).

Two isolates of a species putatively assigned to the genus Candida were also obtained from two different flowers of $H$. psittacorum. The sequences of the D1/D2 domains showed that the species occupied a basal position in the Metschnikowiaceae clade (Fig. 2). The novel species differed by 43 or more substitutions in the D1/D2 sequence from other species and the phenetic sequence distance could not be used to identify a sister species with any degree of confidence. The two isolates were examined either individually or mixed on cornmeal, V8, dilute V8, 5\% malt extract, yeast carbon base supplemented with $0.01 \%$ ammonium sulfate, and Gorodkowa agars incubated at $20{ }^{\circ} \mathrm{C}$ or $28{ }^{\circ} \mathrm{C}$ for 30 days, but asci or signs of conjugation were not seen. The name Candida tocantinsensis sp. nov. is proposed for these two isolates.
Both novel species were obtained from flower bracts of $H$. psittacorum, a plant species that possesses ephemeral flowers and long-standing bracts with extrafloral nectaries. Flowers of Heliconia are a rich source of yeast species, as shown by Ruivo et al. (2006), who described Candida heliconiae, Candida picinguabensis and Candida saopaulonensis, and Rosa et al. (2007), who reported the first occurrence of Candida flosculorum in Heliconia velloziana and Heliconia episcopalis in rainforests of south-eastern Brazil. It is likely that yeasts and bacteria are vectored by hummingbirds and insects to the nectar found in the bracts and grow in this substrate. As 13 strains of $W$. pagnoccae were isolated from 10 flower bracts of $H$. psittacorum, we infer that the yeast is autochthonous to this plant species in the Cerrado region of Jalapão, northern Brazil. Other known heterothallic Wickerhamiella species also occur in association with flowers (Lachance et al., 1998). Wickerhamiella species are highly specialized nutritionally and ecologically. The restricted physiology and the strong association with floricolous insects seem to be characteristic of most other members of the clade (Lachance \& Kurtzman, 2011). In contrast, only two isolates of Candida tocantinsensis were obtained from 15 different samples of flower bracts of $H$. psittacorum, making it more difficult to speculate about the habitat of this novel species. However, other species in the same subclade have been isolated from Heliconia flower bracts, suggesting that this group of species may occur in Heliconia flower bracts and similar substrates in the Brazilian Cerrado ecosystem.

\section{Latin diagnosis of Wickerhamiella pagnoccae Barbosa, Morais, Morais, Rosa, Pimenta, Lachance \& Rosa sp. nov.}

In medio liquido glucosum et extractum levidinis post dies tres cellulae singulae aut binae; cellulae ovoidae $(1.5-3.0 \times 2.0-$ $4.0 \mu \mathrm{m}$ ). Post unum mensem sedimentum formatur. Cultura in agaro malti post dies $2\left(25^{\circ} \mathrm{C}\right)$ parva, convexa, glabra et candida. In agaro farinae Zea mays post dies $14\left(17^{\circ} \mathrm{C}\right)$ mycelium nec pseudomycelium non formantur. Species

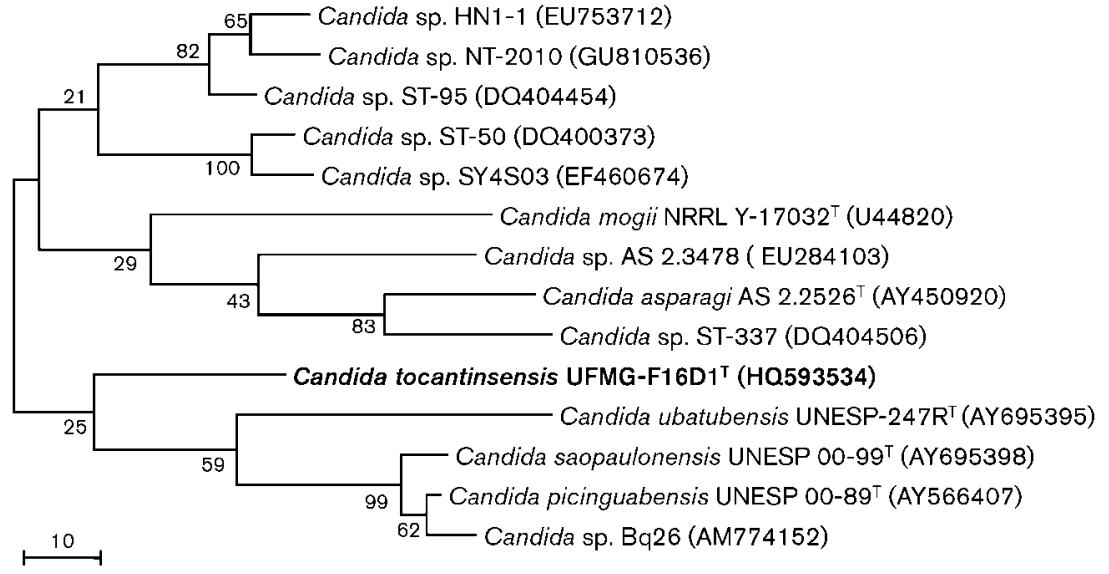

Fig. 2. Phylogenetic placement of Candida tocantinsensis sp. nov. based on maximumparsimony analysis of sequences of the D1/ D2 domains of the large-subunit rRNA gene. A bootstrap consensus tree from 100 replicates is shown; bootstrap values are shown at nodes. The tree was obtained using the Close-Neighbour-Interchange algorithm ( $\mathrm{Nei}$ \& Kumar, 2000) with search level 2 with initial trees obtained by random addition. A total of 374 positions were used in the analysis conducted with the program MEGA4 (Tamura et al., 2007). Bar, number of nucleotide changes. 
heterothallica. Asci ascosporam unam liberant. Glucosum non fermentatur. Glucosum, L-sorbosum, mannitolum, glucitolum, acidum succinicum assimilantur, at non galactosum, maltosum, sucrosum, trehalosum, raffinosum, D-xylosum, Larabinosum, D-arabinosum, D-ribosum, L-rhamnosum, ethanolum, glycerolum, erythritolum, ribitolum, salicinum, acidum lacticum, acidum citricum, xylitolum, acidum gluconicum, inulinum, melibiosum, lactosum, melezitosum, cellobiosum, amylum solubile, D-arabinosum, methanolum, 2-propanolum, galactitolum, myo-inositolum, 2-ketogluconatum, glucosaminum, $N$-acetylglucosaminum, acetonum, ethyl acetas nec hexadecanum. Lysinum assimilatur at non ethylaminum, cadaverinum, natrium nitricum nec natrium nitrosum. Augmentum in $37{ }^{\circ} \mathrm{C}$. Habitat congregation em Heliconia psittacorum in Brazil. Typus: UFMG-F18C1 ${ }^{\mathrm{T}}$. Allotypus: UFMG-F8F2. In collectione zymotica Centraalbureau voor Schimmelcultures, Trajectum ad Rhenum, sub no. CBS $12178^{\mathrm{T}}$ et CBS 12179 deposita sunt.

\section{Description of Wickerhamiella pagnoccae Barbosa, Morais, Morais, Rosa, Pimenta, Lachance \& Rosa sp. nov.}

Wickerhamiella pagnoccae (pag.noc'ca.e. N.L. gen. nom. m. sing. n. pagnoccae of Pagnocca, referring to Professor Fernando Carlos Pagnocca, in recognition of his contributions to yeast systematics and ecology in Brazil).

In $2 \%$ glucose $-0.5 \%$ yeast extract broth after 3 days at $25{ }^{\circ} \mathrm{C}$, cells are ovoid $(1.5-3.0 \times 2.0-4.0 \mu \mathrm{m})$, isolated or in pairs. Budding is multilateral. Sediment is formed after 1 month, but no pellicle is observed. On YM agar after 2 days at $25{ }^{\circ} \mathrm{C}$, colonies are white, convex, smooth and opalescent. In Dalmau plates after 2 weeks at $17{ }^{\circ} \mathrm{C}$ on cornmeal agar, pseudohyphae or true hyphae are not formed. Species is heterothallic. After 1 day on dilute (1:9) V8 agar, mixed strains of complementary mating types give rise to short conjugation tubes. Conjugated pairs, zygotes and asci containing one ascospore are also present (Fig. 3). Ascospores are liberated and agglutinate. Glucose is not fermented. Assimilates the following carbon compounds: glucose, L-sorbose, D-mannitol, D-glucitol and succinic acid. No growth occurs on galactose, maltose, sucrose, trehalose, raffinose, D-xylose, L-arabinose, D-arabinose, Dribose, L-rhamnose, ethanol, glycerol, erythritol, ribitol, salicin, lactic acid, citric acid, xylitol, gluconic acid, inulin, melibiose, lactose, melezitose, cellobiose, soluble starch, methanol, 2-propanol, galactitol, myo-inositol, 2-ketogluconate, D-glucosamine, $\mathrm{N}$-acetylglucosamine, acetone, ethyl acetate or hexadecane. Assimilates lysine, but not ethylamine hydrochloride, cadaverine, nitrate or nitrite. Growth in vitamin-free medium is negative. Growth in amino-acid-free medium is positive. Growth at $37^{\circ} \mathrm{C}$ is positive. Growth on YM agar with $10 \% \mathrm{NaCl}$ is positive. Growth in $50 \%$ glucose- $0.5 \%$ yeast extract is negative. Starch-like compounds are not produced. In $100 \mu \mathrm{g}$ cycloheximide $\mathrm{ml}^{-1}$ growth is negative. Urease activity is negative. Diazonium Blue B reaction is negative. Habitat is flower bracts of Heliconia psittacorum collected in a riparian area of Cerrado ecosystem, in the state of Tocantins, Brazil.

The type strain $\left(\mathrm{h}^{+}\right)$is UFMG-F18C1 ${ }^{\mathrm{T}}\left(=\mathrm{CBS} 12178^{\mathrm{T}}\right.$ $=$ NRRL Y $-48735^{\mathrm{T}}$ ), isolated from flowers of Heliconia psittacorum collected in the riparian area of Formiga Falls, Brazil. The designated allotype $\left(\mathrm{h}^{-}\right)$, UFMG-F8F2 (=CBS $12179=$ NRRL Y-48736), was recovered from flower bracts of $H$. psittacorum at the same collection site.

\section{Latin diagnosis of Candida tocantinsensis Barbosa, Morais, Morais, Rosa, Pimenta, Lachance \& Rosa sp. nov.}

In medio liquido glucosum et extractum levidinis post dies tres cellulae singulae aut binae; cellulae ovoidae $(2.0-3.0 \times 3.0-$ $4.0 \mu \mathrm{m})$. Post unum mensem sedimentum formatur. Cultura in agaro malti post dies $2\left(25{ }^{\circ} \mathrm{C}\right)$ parva, convexa, glabra et candida. In agaro farinae Zea mays post dies 14 mycelium nec pseudomycelium non formantur. Ascosporae non formantur. Glucosum fermentatur. Glucosum, galactosum, L-sorbosum, maltosum, sucrosum, trehalosum (lente), melezitosum, Dxylosum (exigue), D-arabinosum (exigue), ethanolum, ribitolum, mannitolum, glucitolum, acidum succinicum et xylitolum assimilantur, at non raffinosum, L-arabinosum, D-ribosum, L-rhamnosum, glycerolum, erythritolum, salicinum, acidum lacticum, acidum citricum, acidum gluconicum, inulinum, melibiosum, lactosum, cellobiosum, amylum solubile, methanolum, 2-propanolum, galactitolum, myo-inositolum, 2-ketogluconatum, glucosaminum, $\mathrm{N}$-acetylglucosaminum, acetonum, ethyl acetas nec hexadecanum. Lysinum, ethylaminum et
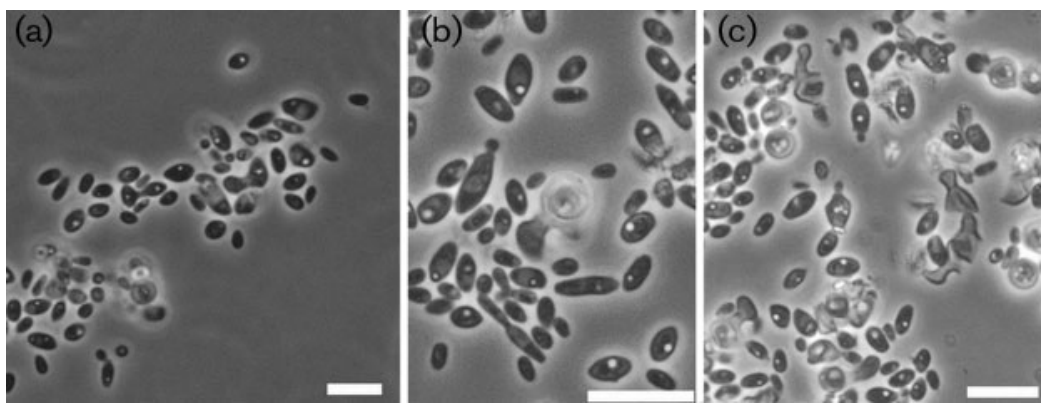

Fig. 3. Phase-contrast micrographs of cells and asci of the complementary mating types of Wickerhamiella pagnoccae sp. nov. grown on dilute (1:9) V8 agar after $24 \mathrm{~h}$. (a) Vegetative and conjugative cells; (b) vegetative cells and an ascus with an emerging ascospore; and (c) vegetative cells, asci, deliquesced asci and released ascospores. Bars, $5 \mu \mathrm{m}$. 
cadaverinum assimilantur, non natrium nitricum nec natrium nitrosum. Augmentum in $37^{\circ} \mathrm{C}$. Habitat congregation in Heliconia psittacorum in Brazil. Typus: UFMG-F16D1 ${ }^{\mathrm{T}}$. In collectione zymotica Centraalbureau voor Schimmelcultures, Trajectum ad Rhenum, sub no. CBS $12177^{\mathrm{T}}$ typus stirps deposita est.

\section{Description of Candida tocantinsensis Barbosa, Morais, Morais, Rosa, Pimenta, Lachance \& Rosa sp. nov.}

Candida tocantinsensis (to.can.tins.en'sis. N.L. nom. fem. sing. adj. tocantinsensis of or belonging to the state of Tocantins, Brazil, where this yeast was found).

In $2 \%$ glucose $-0.5 \%$ yeast extract broth after 3 days at $25{ }^{\circ} \mathrm{C}$, cells are ovoid $(2.0-3.0 \times 3.0-4.0 \mu \mathrm{m})$, isolated or in pairs. Budding is multilateral (Fig. 4). Sediment is formed after 1 month, but no pellicle is observed. On YM agar after 2 days at $25^{\circ} \mathrm{C}$, colonies are white, convex, smooth and opalescent. In Dalmau plates after 2 weeks on cornmeal agar, pseudomycelia or true mycelia are not formed. Sexual spores are not observed. Glucose is fermented. Assimilates the following carbon compounds: glucose, galactose, L-sorbose, maltose, sucrose, trehalose (slow), melezitose, D-xylose (weak), D-arabinose (weak), ethanol, ribitol, mannitol, glucitol, succinic acid and xylitol. No growth occurs on raffinose, L-arabinose, Dribose, L-rhamnose, glycerol, erythritol, salicin, lactic acid, citric acid, gluconate, inulin, melibiose, lactose, cellobiose, soluble starch, methanol, 2-propanol, galactitol, myoinositol, 2-ketogluconate, glucosamine, $\mathrm{N}$-acetylglucosamine, acetone, ethyl acetate or hexadecane. Assimilates lysine, ethylamine hydrochloride and cadaverine; negative for nitrate and nitrite assimilation. Growth in vitamin-free medium is negative. Growth in amino-acid-free medium is positive. Growth at $37{ }^{\circ} \mathrm{C}$ is positive. Growth on YM agar with $10 \% \mathrm{NaCl}$ is negative. Growth in $50 \%$ glucose$0.5 \%$ yeast extract is negative. Starch-like compounds are not produced. In $100 \mu \mathrm{g}$ cycloheximide $\mathrm{ml}^{-1}$ growth is

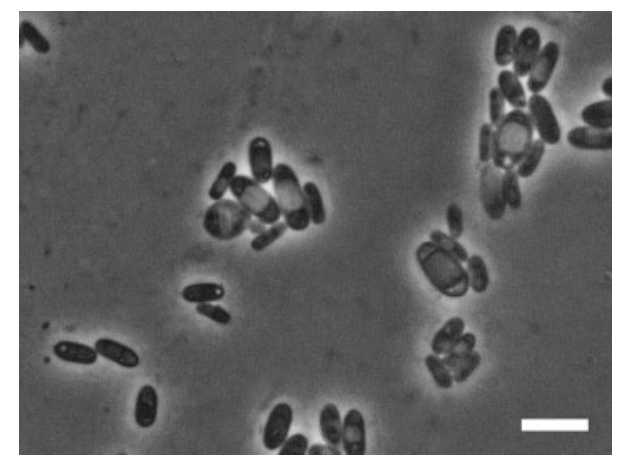

Fig. 4. Phase-contrast micrograph of cells of Candida tocantinsensis sp. nov. grown on yeast nitrogen base with $0.01 \%$ ammonium sulfate after 3 days. Bar, $5 \mu \mathrm{m}$. positive. Urease activity is negative. Diazonium Blue B reaction is negative. Habitat is flower bracts of Heliconia psittacorum collected in a riparian area of Cerrado ecosystem, in the state of Tocantins, Brazil.

The type strain is UFMG-F16D1 ${ }^{\mathrm{T}}\left(=\mathrm{CBS} 12177^{\mathrm{T}}=\mathrm{NRRL}\right.$ $\mathrm{Y}-48734^{\mathrm{T}}$ ), isolated from flowers of $H$. psittacorum collected in the riparian area of Formiga Falls, Brazil.

\section{Acknowledgements}

This work was funded by Conselho Nacional de Desenvolvimento Cientifico e Tecnológico (CNPq - Brazil), Fundação do Amparo a Pesquisa do Estado de Minas Gerais (FAPEMIG), and the Natural Science and Engineering Research Council of Canada (M.-A. L.).

\section{References}

Colli, G. R., Giugliano, L. G., Mesquita, D. O. \& França, F. G. R. (2009). A new species of Cnemidophorus from the Jalapão Region, in the Central Brazilian Cerrado. Herpetologica 65, 311-327.

Gill, F. B. (1987). Ecological fitting: use of floral nectar in Heliconia stilesii Daniels by three species of hermit hummingbirds. Condor $\mathbf{8 9}$, 779-787.

Kurtzman, C. P. \& Fell, J. W. (editors) (1998). The Yeasts, a Taxonomic Study, 4th edn. Amsterdam: Elsevier.

Lachance, M.-A. \& Kurtzman, C. P. (2011). Wickerhamiella van der Walt. In The Yeasts, a Taxonomic Study, 5th edn, pp. 891-897. Edited by C. P. Kurtzman, J. W. Fell \& T. Boekhout. Amsterdam: Elsevier.

Lachance, M.-A., Rosa, C. A., Starmer, W. T., Schlag-Edler, B., Barker, J. S. F. \& Bowles, J. M. (1998). Wickerhamiella australiensis, Wickerhamiella cacticola, Wickerhamiella occidentalis, Candida drosophilae and Candida lipophila, five new related yeast species from flowers and associated insects. Int J Syst Bacteriol 48, 14311443.

Lachance, M.-A., Bowles, J. M., Starmer, W. T. \& Barker, J. S. F. (1999). Kodamaea kakaduensis and Candida tolerans, two new ascomycetous yeast species from Australian Hibiscus flowers. Can J Microbiol 45, 172-177.

Nei, M. \& Kumar, S. (2000). Molecular Evolution and Phylogenetics. New York: Oxford University Press.

Rosa, C. A., Pagnocca, F. C., Lachance, M.-A., Ruivo, C. C., Medeiros, A. O., Pimentel, M. R., Fontenelle, J. C. \& Martins, R. P. (2007). Candida flosculorum sp. nov. and Candida floris sp. nov., two yeast species associated with tropical flowers. Int J Syst Evol Microbiol 57, 2970-2974.

Ruivo, C. C., Lachance, M.-A., Rosa, C. A., Bacci, M., Jr \& Pagnocca, F. C. (2006). Candida heliconiae sp. nov., Candida picinguabensis sp. nov. and Candida saopaulonensis sp. nov., three ascomycetous yeasts from Heliconia velloziana (Heliconiaceae). Int J Syst Evol Microbiol 56, 1147-1151.

Schnittler, M. \& Stephenson, S. L. (2002). Inflorescences of neotropical herbs as a newly discovered microhabitat for myxomycetes. Mycologia 94, 6-20.

Schumann, K. M. (1900). Musaceae. In Das Pflanzenreich, vol. IV, pp. 1-45. Edited by A. Engler. Leipzig: Engelmann.

Stiles, G. F. (1975). Ecology, flowering phenology, and hummingbird pollination of some Costa Rican Heliconia species. Ecology 56, 285301. 
Tamura, K., Dudley, J., Nei, M. \& Kumar, S. (2007). MEGA4: Molecular Evolutionary Genetics Analysis (MEGA) software version 4.0. Mol Biol Evol 24, 1596-1599.

Taylor, J. \& White, S. A. (2007). Observations of hummingbird feeding behavior at flowers of Heliconia beckneri and H. tortuosa in southern Costa Rica. Ornitol Neotrop 18, 133-138.
Weberling, F. (1982). Current problems of modern inflorescence morphology. Austral Syst Bot Soc Newsl 30, 5-21.

Yarrow, D. (1998). Methods for the isolation and identification of yeasts. In The Yeasts, a Taxonomic Study, 4th edn, pp. 77100. Edited by C. P. Kurtzman \& J. W. Fell. Amsterdam: Elsevier. 